\title{
The Cosmos in Clay: An Analysis of Avery Engraved Vessel Motifs
}

Louisa Nash

Cornell University

Follow this and additional works at: https://scholarworks.sfasu.edu/ita

Part of the American Material Culture Commons, Archaeological Anthropology Commons, Environmental Studies Commons, Other American Studies Commons, Other Arts and Humanities Commons, Other History of Art, Architecture, and Archaeology Commons, and the United States History Commons

Tell us how this article helped you.

This Article is brought to you for free and open access by the Center for Regional Heritage Research at SFA ScholarWorks. It has been accepted for inclusion in Index of Texas Archaeology: Open Access Gray Literature from the Lone Star State by an authorized editor of SFA ScholarWorks. For more information, please contact cdsscholarworks@sfasu.edu. 


\section{The Cosmos in Clay: An Analysis of Avery Engraved Vessel Motifs}

Creative Commons License

(c) (i) (8)

This work is licensed under a Creative Commons Attribution-NonCommercial 4.0 International License 


\title{
The Cosmos in Clay: An Analysis of Avery Engraved Vessel Motifs
}

\author{
Louisa Nash \\ Cornell University
}

This study seeks to provide new interpretations for the abstract and geometric Avery Engraved vessel motifs created by the prehistoric Caddo. I argue that certain motifs represent wings, feathers, and the Upper World, while other motifs act as locatives and are representative of the Lower World in the Caddo conception of a tiered universe. Given the nature of archaeological research, it is not possible to ascertain all of the implications, nuances, and complexities of the motifs that appear on Avery Engraved vessels. However, this study and others like it, which work to extrapolate the meaning of motifs through comparative analysis with representational engraved shell imagery and through the use of ethnographic and ethnohistoric data, can enrich our knowledge about how the Caddo rendered and communicated core beliefs in nonrepresentational ways.

\section{Introduction}

The prehistoric Caddo, who lived in present-day southwest Arkansas, northwest Louisiana, eastern Oklahoma, and northeast Texas from about A.D. 8001700, were highly skilled potters who created intricate designs on a variety of vessel structures. In addition to routine food preparation, storage, and serving uses, pottery was a highly visible medium that was used during community feasts, religious rituals, and burial ceremonies as grave goods (Townsend and Walker 2004:245). Caddo potters did not create figural designs on their vessels but instead adorned their pottery with nonrepresentational motifs that likely pertained to important cultural, religious, and cosmological themes. A decoration type known as Avery Engraved portrays motifs that have traditionally been interpreted by scholars as relating to the celestial Upper World in the Caddo conception of a tiered universe by representing the sun (Pauketat and Emerson 1991:928).

However, after comparing the abstract geometric motifs on Avery Engraved vessels with representational images from the broader corpus of Caddo religious imagery found principally on engraved shell cups from Caddo sites, and considering recent Caddo iconographic studies and ethnographic and ethnohistoric analogies, I believe that Avery Engraved vessels actually portray motifs that directly reference specific aspects and beings of both the Upper and Lower Worlds. Additionally, the Upper World is likely referenced by motifs that symbolize feathers rather than the sun. The relation of Avery Engraved motifs to the Lower World has not, to my knowledge, been discussed to any great length in the literature. Yet, within this study's sample size of 132 Avery Engraved vessels, Lower World motifs had been used in conjunction with Upper World ones to reference fundamental religious beliefs concerning the tiered cosmos, beings of power, and the journey to the afterlife. These new interpretations of Avery Engraved motifs provide a greater understanding of how abstract, geometric motifs were used by the Caddo as referents and locatives that conveyed nuanced aspects of the dualistic and opposing realms of the universe.

In this article, I provide some basic background on the culture and society of the prehistoric Caddo. Next, the methodology and use of a comparative iconographic approach and the use of ethnographic and ethnohistoric material are considered. I then demonstrate through the analysis of Avery Engraved vessels from burials located in Texas, Arkansas, and Oklahoma how motifs, in both isolation and in combination, were placed on vessels in order to derive particular cosmological and religious associations with either Upper, Lower, or both worlds. This study further elucidates how the Caddo expressed religious themes through both the medium of ceramics and through nonrepresentational imagery.

\section{Caddo Culture and Society}

The Caddo people, whose complex and distinctive culture has been the focus of many archaeological 


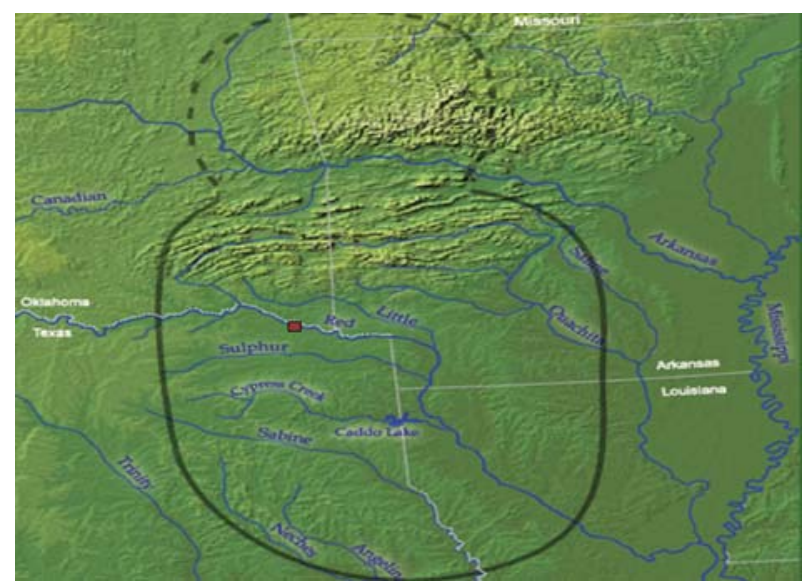

Figure 1. Map of the Caddo region. Solid line shows primary area; dashed line represents the northern extent of Caddo habitation (from Texas Archaeological Research Laboratory, 2010). Box features the generalized location of the Roden, Sam Kaufman, and Bob Williams sites, all of which contain Avery Engraved Vessels.

studies, are considered to be linked together by a common cultural and historical heritage (Perttula 1996, 2012). From about A.D. 800 into historic times, the Caddo people lived as distinct communities and social groups in principally sedentary dispersed settlements, with civic-ceremonial centers near the edge of communities. These communities were comprised of isolated farmsteads, several larger villages with groups of farmsteads, and the civic-ceremonial centers that were visited by individuals from nearby settlements (Perttula 2012).

The region that the Caddo traditionally inhabited, as evidenced through archaeological investigation and ethnohistoric and historic accounts, centers on the Red River and its tributaries (Perttula 1996). This includes areas in present southwest Arkansas, northwest Louisiana, eastern Oklahoma, and northeast Texas, as shown in Figure 1 (Perttula 2012). For this study, analysis will focus on whole Avery
Engraved vessels originating from sites in Arkansas, Texas, and Oklahoma from around the Middle to Late Caddo periods. The temporal duration of Caddo chronology can be divided into five general periods, as seen in Table 1; these period divisions are based upon broad trends seen in the archaeological record (Dowd 2011b; Perttula 1996). Regional phases further delineate specific social and cultural changes.

The McCurtain Phase, a regional phase of the Middle Red River, begins at A.D. 1300, ends at A.D. 1700 , and roughly corresponds to the Middle and Late Caddo periods. Sites occurring during this phase are located along the Red River drainage and also along the Little River drainage (Dowd 2011b:6). This phase saw a variety of red slipped vessels including Avery Engraved, Clement Redware or Roden ware, and Simms Engraved, (University of Oklahoma, Oklahoma Archeological Survey [OAS]) and it was during the entirety of the McCurtain Phase that Avery Engraved vessels occurred most frequently (Dowd 2012). Over the course of the McCurtain Phase vessels featured different body forms and motifs. By the end of the McCurtain Phase, around A.D. 1700, Avery Engraved vessels had largely been "replaced by conical Taylor and Hodges Engraved vessels" (Perino 1983:74).

McCurtain Phase settlements were generally villages "with substructural mounds, household cemeteries, shaft tombs for multiple burials, and house sites scattered along major and minor drainages" (University of Oklahoma, OAS). Some settlements were connected to civic-ceremonial and mound centers. The civic-ceremonial centers were formed using one or more platform or conical earthen mounds situated around a large plaza. Structures, like temples, were sometimes built on flat platform mounds. Conical mounds frequently contained burials and ceremonial fire mounds were also used for public and religious functions and

\begin{tabular}{|l|l|l|l|}
\hline Periods & Period Dates (A.D.) & $\begin{array}{l}\text { Phases of the Middle } \\
\text { Red River Area }\end{array}$ & Phase Dates (A.D.) \\
\hline Formative Caddo & $800-1000$ & Albion & $900-1100$ \\
\hline Early Caddo & $1000-1200$ & Mound Prairie & $1100-1300$ \\
\hline Middle Caddo & $1200-1400$ & Early McCurtain & $1300-1500$ \\
\hline Late Caddo & $1400-1680$ & Late McCurtain & $1500-1700$ \\
\hline Historic Caddo & $1680-1860+$ & Historic & $1700-1730+$ \\
\hline
\end{tabular}

Table 1. Caddo period and phase chronology (adapted from Dowd 2011b; Perttula 2012). 
celebrations (Perttula 1996:306). Elaborate ceremonies and mortuary rituals were conducted at mound centers, with the socially and politically elite members of society buried in shaft tombs accompanied by exotic, rare, and elaborately made grave goods (Perttula 1996, 2012). Certain Avery Engraved vessels, particularly bottles, have also been discovered in the context of shaft tombs and mound burials (Skinner et al. 1969). Caddo society during both prehistoric and historic times was socially ranked and matrilineal descent is evident through kinship terms (Dowd 2011b; Perttula 2012:9).

Caddo societies share many features with their southeastern neighbors, such as the utilization of and intensification in the production of maize, social and political ranking with recognized elites, and complex ceremonies comparable in nature to other Mississippian societies. While some archaeologists believe the Caddo to be a western or peripheral expression of the larger Mississippian world (Blitz 2010), other scholars argue that the Caddo developed independently (Perttula 1996, 2012). Presently, many scholars conducting research on Mississippian societies, cultures, and iconographies acknowledge and emphasize local, regional, and temporal variation and diversity (Knight et al. 2001; Reilly 2004; Reilly and Garber 2007:1).

\section{The Southeastern Ceremonial Complex}

First synthesized in 1945, the Southeastern Ceremonial Complex (SECC) focuses on a body of icons and artistic motifs that are believed to portray the principle ideologies of Mississippian religion (Waring and Holder 1945). The corpus of the SECC predominantly features subjects such as ancestors, nature, animals, warfare, and the transformation or hybridization of animals, humans, and objects into one another (Simek et al. 2012:196). The definition of the SECC has undergone a number of revisions regarding type and content of iconographic depictions, thematic messages, and stylistic classifications. With certain images and styles crossing spatial and temporal boundaries, it is emphasized that "variation in styles, genres, thematic content, and chronology" should be more adequately studied to better understand Mississippian art, society, and religion (Knight et al. 2001:130).

Investigation into symbolically significant themes and motifs, especially from traditional SECC studies, has primarily focused on a wide variety of material types largely exclusive of nonrepresentational ceramic vessels. Materials such as engraved shell cups and gorgets, copper masks and repoussé, effigy statues, and vessels were often at the center of discussions pertaining to religious and ritual significance (Knight et al. 2001). Studies on ceramics have chiefly been concerned with "identity and degrees of social interaction between different groups" (Dowd 2011b:1; Krieger 1946; Perttula 1992), utilitarian uses (Braun 1983), research on "household size, prehistoric diet, trade patterns, learning networks, change" (Rice 1996:138), social and political status (Pauketat and Emerson 1991), and the establishment of relative chronologies. Decoration on pottery is now "interpreted within a broader realm of stylistic behavior," and investigations into cultural and religious meanings have now become more prominent (Gadus 2013; Rice 1996:149).

Caddo vessels were decorated using abstract and geometric designs instead of the representational iconography of the broader SECC (Townsend and Walker 2004; Reilly 2004:126). This variation appears deliberate, as representational imagery is found on other Caddo items, like engraved marine columella shell cups and gorgets, at Caddo sites such as the Spiro site and Roden Mounds site in Oklahoma and Texas respectively. Geometric and abstract designs unaccompanied by other representational figures can make attaching particular cosmological associations to these designs difficult; however, ascertaining general symbolic meaning is still possible (Lankford et al. 2011; Philips and Brown 1978; Reilly and Garber 2007). Potential meanings or associations of nonrepresentational motifs can be suggested by iconographical studies that center on the comparison of abstract motifs with representational imagery. These studies can be further supported by ethnographic and ethnohistoric accounts.

The principle thematic meaning traditionally related to Avery Engraved vessels is that of the celestial realm because arcs, especially rayed and ticked arcs, are believed to be related to the "sun circle" motif and to represent sunrises (Perino 1983; Phillips and Brown 1978; Waring and Holder 1945:4). The sun circle motif has long been considered a principle motif in the SECC (Waring and Holder 1945:4). However, given the specific types of primary and secondary 
motifs uncovered during the course of this study, I believe that there is more nuance and variance to Avery Engraved vessel motifs than this simple assessment. Many vessels have motifs of crosshatching, "SZ", and interlocking ends that are related with the Lower World. The means by which motifs are associated with different cosmological realms are largely through studies of representational imagery, like the kind found on engraved shell cups, along with ethnographic and ethnohistoric accounts.

\section{Theoretical and Methodological Approaches}

The methodology that has been employed to investigate the relationship between Avery Engraved vessel motifs and associated religious meaning emphasizes the use of visual analysis. This form of analysis is frequently used in art history, in which the individual elements and larger context of images are examined and discussed (Writing Studio Duke University 2016). This analysis of Avery Engraved vessels will recognize and consider the following: (1) the primary and secondary design motifs; (2) the relationships among various motifs; (3) how motifs differ based on certain vessel forms, such as bottles. As particular designs are discussed, certain terms may require clarification. Theme can be understood as "a large-scale design or combination of design elements," while a motif is considered "a smaller design unit" that is distinctive (Muller 1989:12). When referring to individual components of a motif, the term element is used. Representational images are those that clearly portray an identifiable image, such as an animal, human, or supernatural being. While some images may seem to imply or suggest a referent, if they do not portray a recognizable form then images are referred to here as nonrepresentational. Nonrepresentational images often do not intend to "present an accurate depiction of the physical appearance of people or things" (Oxford Living Dictionaries 2016).

Studies that investigate iconography, especially nonrepresentational iconography on vessels, provide an entirely new avenue of investigation into how prehistoric communities structured, replicated, retained, and transmitted their religious worldviews (Gadus 2013). This study builds upon previous iconographic studies including those conducted by Fields and
Gadus 2012, Gadus 2013, Lankford et al. 2011, Philips and Brown 1978, and Reilly and Garber 2007. The iconographic studies done by Fields and Gadus (2012) and Gadus (2013) focus upon the comparison of engraved shell cups and Caddo vessels, such as Ripley Engraved bottles. Gadus (2013) concluded that important cosmological and iconographic themes including the tiered universe, "the sacred pole, fierce birds, twisted serpents, and the Great Serpent" could be related with images on Ripley Engraved, Johns Engraved, and Wilder Engraved bottles. Similarly, for this study the connection between symbolic imagery and cosmological worldviews is considered. Symbols, including religious symbols, are organized into complex systems (Gertz 1973), and archaeologists are able to study these systems through material remains because "ideology is materialized in objects," and "symbols are material things that can be manipulated and used by people in the past" (DeMarrais et al. 1996; Fogelin 2007:65; Robb 1998, 1999). Symbolic imagery, including Avery Engraved vessel motifs, enabled the Caddo to graphically express core cosmological beliefs that were a central part of their social and cultural identity.

In this study, information on vessels has been obtained from the George T. Wright collection curated at the Sam Noble Oklahoma Museum of Natural History, from site report descriptions and photographs, and from photographs of vessels from various sites and museum collections compiled by the Arkansas Archeological Survey (ARAS). A total of 132 vessels were analyzed from sites in Arkansas, Oklahoma, and Texas. Of these 132 vessels, 12 are bottles, 14 are jars, two are effigy vessels, and 104 are bowls.

These vessels originated from a minimum of 27 sites across Arkansas, Oklahoma, and Texas. The exact number of sites is uncertain, because many vessels in this study were donated to museum collections with an unclear provenience. In some instances, Avery Engraved vessels taken from several sites were amassed by individuals into different collections that were later donated to museums. In contrast with carefully recorded archaeological excavations, these collecting practices have resulted in some Avery Engraved vessels having very little contextual information. This lack of provenience presents serious limitations as to the 
types of research questions that can be addressed. For example, the role of Avery Engraved vessels in regard to questions of gender and social status would presently be difficult to ascertain from many museum collections because collectors and looters frequently did not determine or record information about the age, sex, and status of the individual with whom the vessels were buried.

The known sites and collection were chosen because of the availability of information and images for whole vessels that they provide, as well as the fact that these sites represent relatively contemporaneous McCurtain phase communities. These sites are also representative of different regions, allowing for a wider comparative sample. The availability of images was particularly important for this study, as only images of whole vessels were analyzed. In some instances, different sides and angles of vessels were shown in photographs allowing for a more complete view of a vessel. However, the majority of vessels had photographs with only one view. While many Avery Engraved vessels were recorded as having repeating motifs that occurred around the vessel, it is important to note that this was not verified by a physical examination. The nuances that a complete, in-person view would supply therefore could not be ascertained, and the following interpretation is based upon an extrapolated understanding of each vessel's motif structure. The engraved shell used in this study consists of a gorget from the Roden Site and the published works of Phillips and Brown (1978, 1984), which depict over 300 plates that feature rubbings and line drawings of engraved shell cups, cup fragments, gorgets, and gorget fragments from Craig Mound at the Spiro site in Oklahoma.

Only images of whole vessels have been analyzed in this study; small sherds, whether decorated or plain, are difficult to classify under the Avery Engraved decoration type. This problem arises because "types were defined from complete vessels that often had different decorative patterns on vessel rims and bodies" (Girard 2012:255). Caddo potters in particular often used "different interchangeable techniques and designs on the rims and bodies of their vessels" (Dowd 2012:139). Additionally, it is difficult to determine the complete motif and to note the frequency of motif co-occurrence from smaller sherds. Sherds also make it harder to identify the exact positions of motifs on vessels and any relationships among motif elements.

While sherds from Avery Engraved vessels occur throughout sites, such as in storage or refuse pits in the floors of houses, burials are the chief location at each site where whole Avery Engraved vessels are found; therefore, for this study, Avery Engraved vessels from burials are primarily used. As most or all of these vessels were interred with individuals, the vessels form a comparable data set since they "are all from discrete contexts and had similar functions and social meanings" (Dowd 2011b:33). The engraved shell cups and gorgets were primarily found deposited in Craig Mound at the Spiro site, which also contained burials.

Early ethnographic works, such as those written by Dorsey (1905), Fletcher (1903), and Swanton (1928, 1929, 1942, 1946), provide information on the beliefs, organization, and cultural traditions of the Caddo and other Southeastern peoples. Further ethnographic and ethnohistoric material has been drawn from native peoples in the Muskogean, Algonkian, Caddoan, and Siouan language families (Dowd 2011a:87; Hall 1997). These groups share a number of cosmological beliefs and parallels among their mythologies despite their diverse languages, cultures, and geographies (Dowd 2011a:87). While scholars recognize the acute importance of interpreting the iconography of a particular society based upon that society's specific material, these "shared beliefs have allowed for the development of a general Southeast cosmological model, which has proven useful for identifying certain iconographic themes" (Dowd 2011a:87). These iconographic themes can then guide researchers as they assess the specific contexts, mythologies, and ethnographies of groups, since shared motifs may have had different meanings across different peoples. Wherever possible, Caddo mythology and sites are used to interpret Avery Engraved vessel motifs.

\section{Avery Engraved Motifs}

Avery Engraved vessels were formally described in 1962 in the Handbook of Texas Archaeology: Type Descriptions, edited by D. A. Suhm and E. B. Jelks. The Handbook describes Avery vessels as having "several concentric semicircles, all plain lines, [or] plain lines 


\begin{tabular}{|c|c|c|c|c|c|c|c|}
\hline $\begin{array}{l}\text { Primary } \\
\text { Motif }\end{array}$ & $\begin{array}{l}\text { Total } \\
\text { Number } \\
\text { of Vessels }\end{array}$ & $\begin{array}{l}\text { Total } \\
\text { Number } \\
\text { of Bottles } \\
\text { and Jars }\end{array}$ & $\begin{array}{l}\text { Total } \\
\text { Number } \\
\text { of } \\
\text { Bowls }\end{array}$ & Secondary Motifs & $\begin{array}{l}\text { Total } \\
\text { Number } \\
\text { of Vessels }\end{array}$ & $\begin{array}{l}\text { Total } \\
\text { Number } \\
\text { of Bottles } \\
\text { and Jars }\end{array}$ & $\begin{array}{l}\text { Total } \\
\text { Number } \\
\text { of Bowls }\end{array}$ \\
\hline $\begin{array}{l}\text { Rayed arcs } \\
\text { (placement } \\
\text { of rays } \\
\text { varies) }\end{array}$ & 35 & 4 & 31 & Hatching $(|/| / \mid)))$ & 55 & 14 & 41 \\
\hline $\begin{array}{l}\text { Concentric } \\
\text { Circles }\end{array}$ & 23 & 16 & 7 & Circle & 37 & 13 & 24 \\
\hline Plain arcs & 23 & 3 & 20 & Crosshatching & 22 & 2 & 20 \\
\hline $\begin{array}{l}\text { Ticked arcs } \\
\text { 消E } \\
\text { (placement } \\
\text { of ticks } \\
\text { varies) }\end{array}$ & 17 & 2 & 15 & Rectilinear lines I/ & 19 & 2 & 17 \\
\hline $\begin{array}{l}\text { Interlocking } \\
\text { ends }\end{array}$ & 11 & 4 & 7 & Triangle $\nabla \Delta$ & 17 & 1 & 16 \\
\hline $88 \infty$ & 11 & 3 & 8 & sz $\quad 3800$ & 17 & 10 & 7 \\
\hline $\begin{array}{l}\text { Triangle } \\
\nabla \Delta\end{array}$ & 9 & 0 & 9 & Curvilinearlines $\sim$ & 11 & 4 & 7 \\
\hline Zig-zag & 5 & 0 & 5 & 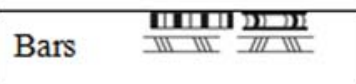 & 7 & 2 & 5 \\
\hline (C) & 5 & 0 & 5 & Oval $\quad \infty$ & 7 & 1 & 6 \\
\hline Diamond & 3 & 1 & 2 & Half circle $\bigcap$ & 6 & 2 & 4 \\
\hline $\begin{array}{l}\text { Circle } \\
\bigcirc\end{array}$ & 2 & 1 & 1 & Diamond & 1 & 0 & 1 \\
\hline $\begin{array}{l}\text { Curvilinear } \\
\text { lines } \sim\end{array}$ & 1 & 0 & 1 & & & & \\
\hline Half circle & 1 & 0 & 1 & & & & \\
\hline $\begin{array}{l}\text { Primary } \\
\text { Motif Total: }\end{array}$ & 146 & 34 & 112 & Secondary Motif Total: & 199 & 51 & 148 \\
\hline
\end{tabular}

Table 2. Principle primary and secondary motifs recorded from the vessels in this study, also the number of vessels each motif occurred on. Multiple primary and secondary motifs may occur on the same vessel (images of SZ, bars, swirl/spiral, and interlocking ends from Gadus 2013:221).

alternated with ticked lines" that repeat around the vessel, usually four times (Suhm and Jelks 1962:1). These repeating semicircular or oval arc motifs can also have small triangular shaped scalloping along the lines of the arc, which are referred to as rayed arcs in this study (Table 2). Arc motifs are often divided by bands that can include motifs such as bars, circles, hatching, and the SZ motif.

Motifs that appear on Avery Engraved vessels in this study are shown in Table 2 . The primary motifs are the ones that are given prominence on the vessel, usually by being the largest and centrally placed 


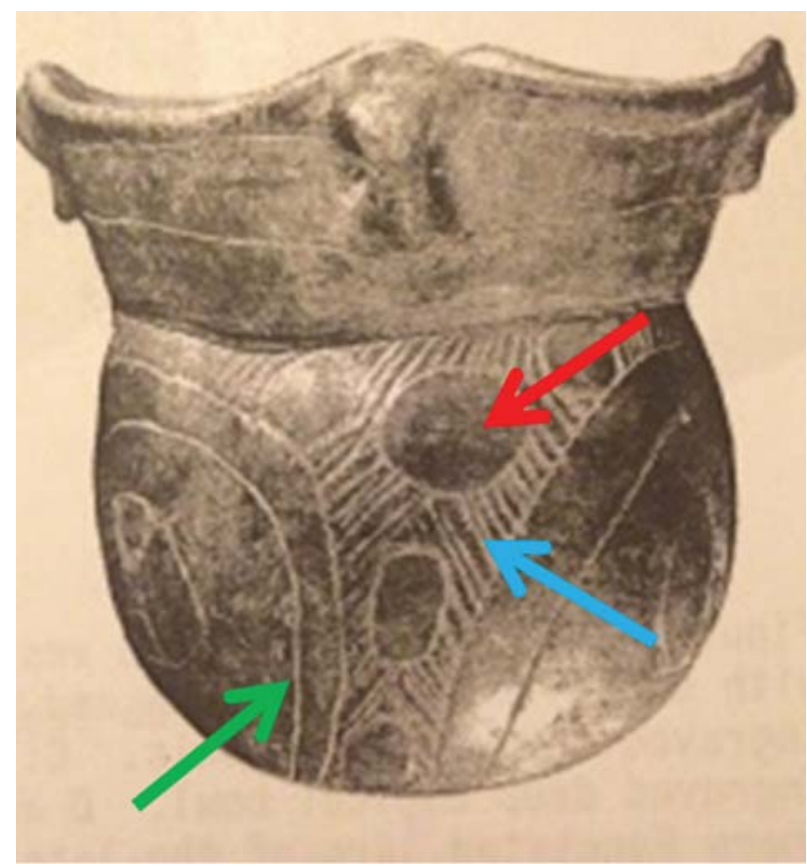

Figure 2. A jar from the Bob Williams Site with circles (red arrow), concentric circles (green arrow), and hatching (blue arrow) (Perino 1983).

(Gadus 2013:220). Secondary motifs frequently appear alongside primary motifs, but these are often smaller and less centrally located. Secondary motifs regularly serve to divide the repeating primary motifs. Generally, secondary motifs "appear to take on a modifying role" in relation to primary motifs (Gadus 2013:220). Some motifs were used interchangeably as primary and secondary motifs. Due to the small number of bottles and jars present in this study, and the general difference in motifs between these vessel types and bowls, bottles and jars have been listed separately from bowls (see Table 2).

The arc, which is comprised of concentric half circle elements, is the dominant motif of Avery Engraved bowls. However, there is a good deal of variance in this typology, as Table 2 demonstrates. As shown in Figures 2 through 5, Avery Engraved motifs can be expressed on a variety of different vessel structures such as bottles, jars, simple bowls, carinated bowls, compound bowls, composite bowls, and effigy vessels. Motifs may vary due to the structure of the vessels and differences in space, as "decorative fields of different sizes will differ in their physical visibility" (Braun 1991:367). Of the vessels examined, bottles and some jars appear to differ from bowls in terms of which

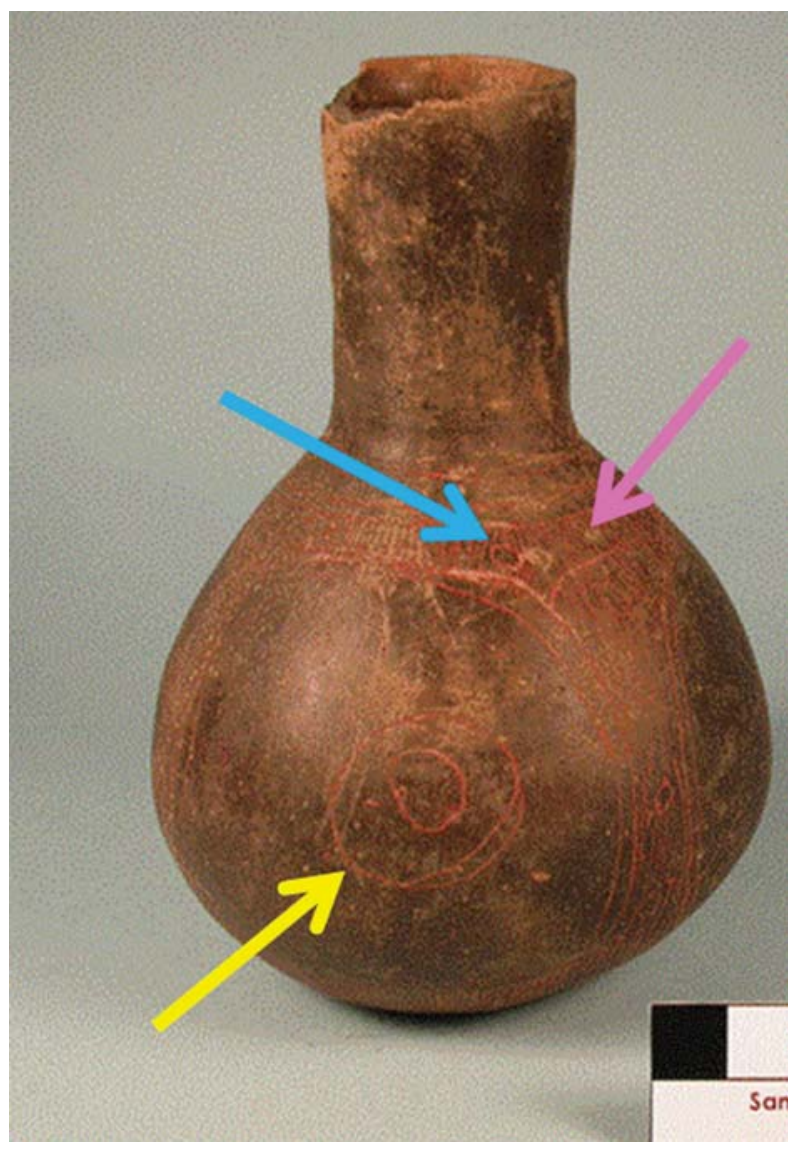

Figure 3. A bottle featuring concentric circles (yellow arrow), circles (blue arrow), and hatching (pink arrow) from the George T. Wright collection.

motif is considered primary. While the vast majority of bowls have a primary motif of an arc, nearly all bottles and many jars have concentric circles as a primary motif. As bowls comprise the majority of vessels in this study, the following discussion is focused on the arc motif on bowls. Currently, it does not appear that scholars have performed residue analyses on Avery Engraved vessels to determine food or drink contents; therefore, at present, it is not possible to attribute motif variance to the past contents of these vessels or to the role these vessels played in serving and storing food or drinks. 


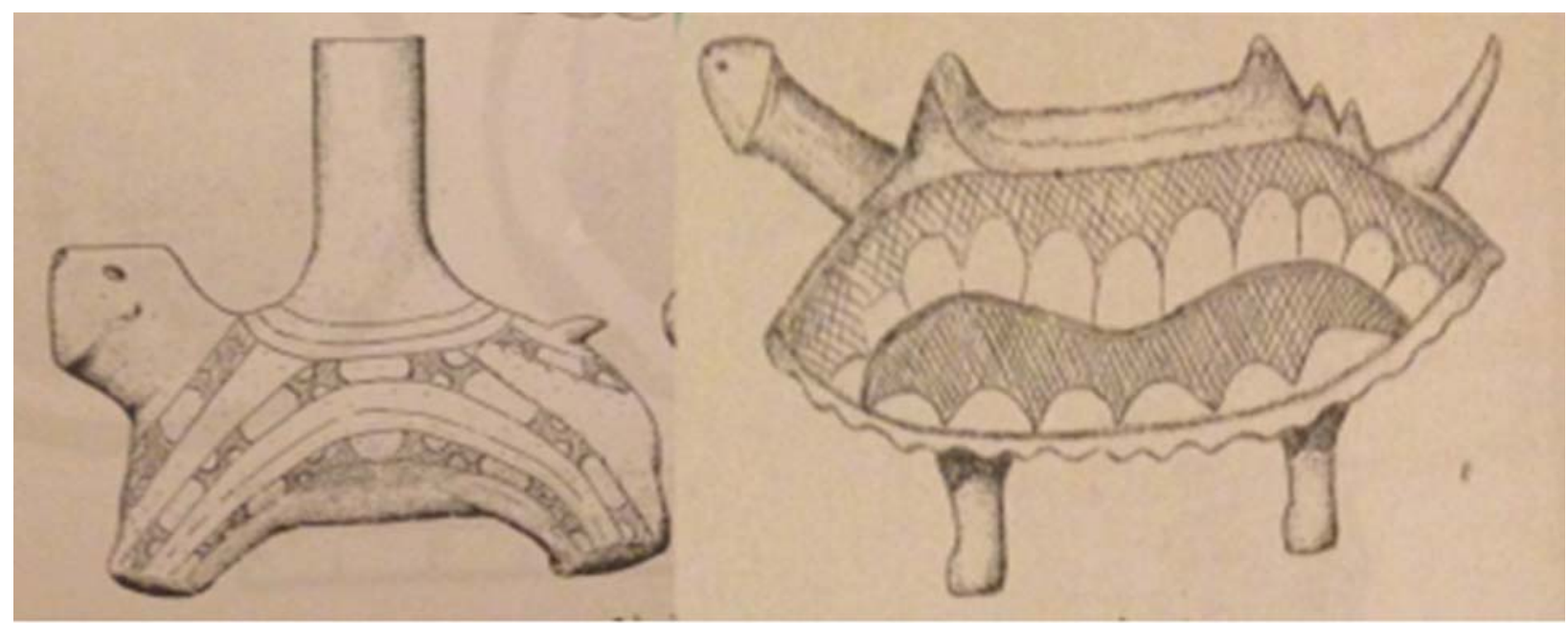

Figure 4. Bear and turtle effigy vessels from the Roden Site (Perino 1981:8).

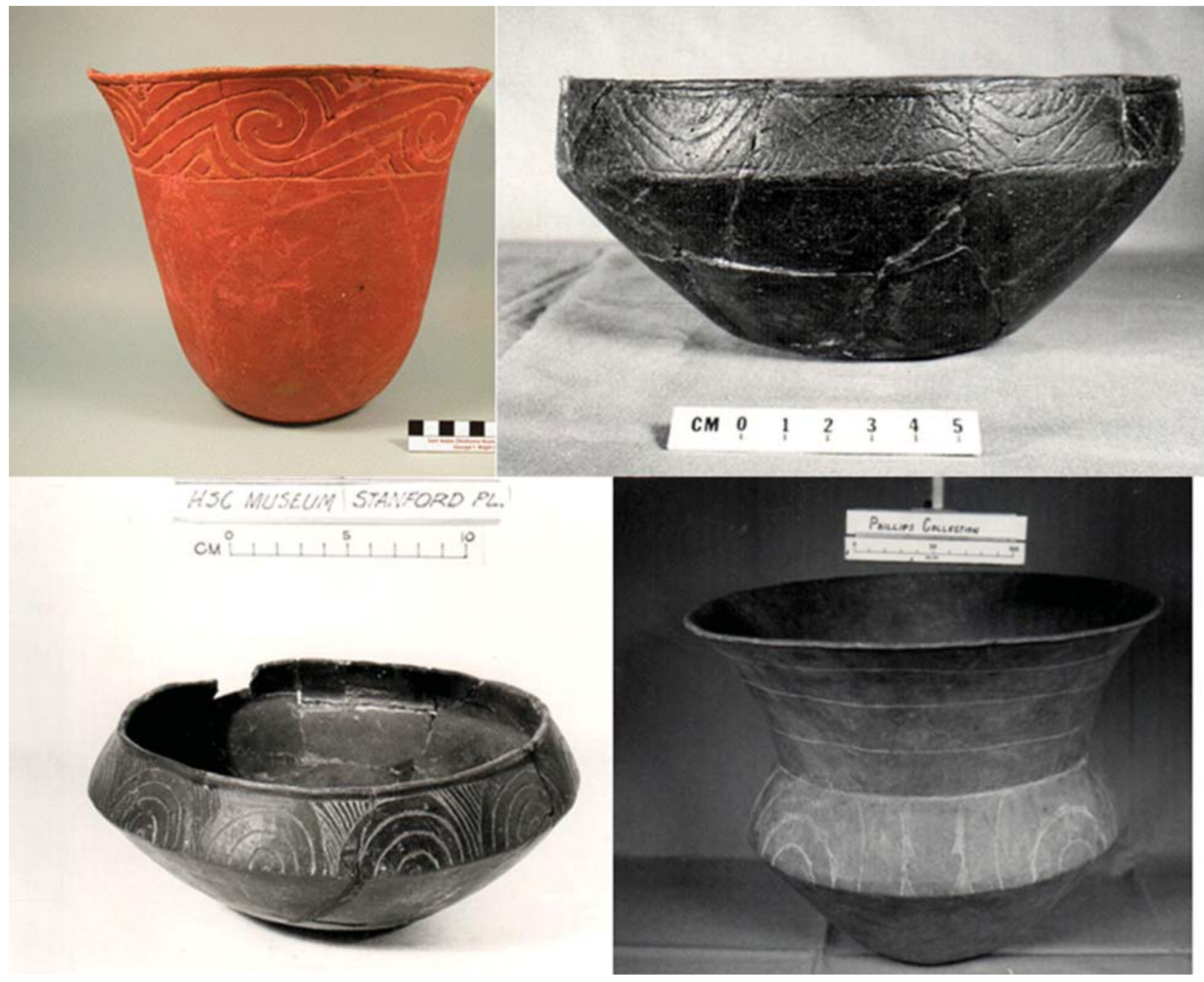

Figure 5. Avery Engraved bowls. Top left: a simple bowl featuring a complex design of interlocking ends that are connected to form an SZ motif (from the George T. Wright Collection). Top right: a carinated bowl with plain arcs (image from Arkansas Archeological Survey). Bottom left: a compound bowl with plain arcs that are separated by hatching. Bottom right: composite bowl with rayed arcs (images from Arkansas Archeological Survey). 


\section{Cosmological Associations with Motifs: Discussion}

\section{Tiered Universe}

Ethnohistoric accounts show that the cosmological model for the Caddo, as well as for other Southeastern groups, is that of a tiered universe consisting of three principle layers. The Upper or Above World is a celestial realm that consists of air as well as some solid elements on which beings reside. It is home to forces such as the sun, the Thunderbirds, and the four directional powers, sometimes referred to as the wind powers (Dowd 2011a:88). The Middle World is the realm that humans, animals, and plants inhabit. Finally, the Lower or Beneath World consists mostly of water (Lankford 2007a:15). Some of the "forces representing the Beneath World include the Great Serpent, water spirits such as snakes and panthers, and sometimes serpents that held the Middle World in place at each of the four corners" (Dowd 2011a:88).

Relating to celestial phenomena, the Upper World is conceived of as being predictable, cyclical, and associated with order and structure (Lankford 2008:95). The Lower World lacks predictability and is related with change, fertility, and unexpected events such as natural disasters (Lankford 2008:95). Hudson (1975:127) clearly delineates the dualism of the Upper and Lower Worlds: "the Upper World represented structure, expectableness, boundaries, limits, periodicity, order, stability, and past time. The Under World represented inversions, madness, invention, fertility, disorder, change, and future time." These realms carried no moral connotations since "the Under World is not evil, nor is the Upper World good" (Lankford 2008:95). The dual and opposing nature of these realms contrasted with each other but was considered by Southeastern people to be the natural structure of the cosmos. The principle goal of people residing in the Middle World was to maintain balance between these two opposing realms (Lankford 2008:95).

The dualism between the Upper and Lower Worlds is discussed in ethnographic accounts of Caddo beliefs. It is presently "unclear to what extent this dualism is incorporated into artistic expressions in the Caddo area" (Dowd 2011a:90-91). It is sometimes portrayed on engraved shell cups and gorgets, which can feature images relating to serpentine, avian, human, and feline subjects. The figures that feature combinations of avian and serpentine attributes are likely representative of Upper and Lower World themes and may explore the relationship between these opposing powers (Phillips and Brown 1978, 1984). Similarly, other types of Caddo vessels, such as Ripley Engraved, Wilder Engraved, and Johns Engraved, have been analyzed and argued as representing themes related to the Upper World and Great Serpent, Lower World, and the Middle World, respectively (Gadus 2013:243). This study on Avery Engraved vessel motifs further contributes to the exploration of the degree of cosmic dualism that has been artistically expressed by the Caddo.

\section{Upper World Imagery on Avery Engraved Vessels}

Historically, the Upper World was perceived by Southeastern tribes as existing above a sky arch or vault from which the Middle World was suspended (Hudson 1976). The common arc motif found on Avery Engraved vessels is possibly related to this concept of a sky vault or arch. During a study of Ramey vessel iconography, Pauketat and Emerson (1991:928) suggested that the similar arc motif found on Ramey vessels may have been representative of such a sky arch and therefore a reference to the layered cosmos. Others have suggested that the arcs found on Mississippian vessels, such as Ramey vessels, actually symbolize rainbows (Hall 1973; Pauketat and Emerson 1991).

The most readily available interpretation for arcs, particularly ticked or rayed arcs, is that these images relate to either the sun or fire (Pauketat and Emerson 1991:928). Traditionally, rayed circles, the cross-in-circle motif, and even isolated circles have been believed to represent the sun (Waring and Holder 1945). Since it is impossible to know with complete certainty what these images represented, the arcs on Avery Engraved vessels may very well still represent either the sunrise or sunset. Fire is also possibly represented by these arcs. Among historic Southeastern tribes, fire was often considered a representation of the sun or as an intelligent entity that worked with the sun (Swanton 1928:208). Furthermore, the Caddo had an important relationship to the moon, and these arcs may in fact 
represent the moon and rays of moonlight (Dorsey 1905; Miller 1996). While any of these interpretations may be perfectly valid, it can only serve to broaden our understanding of nonrepresentational Caddo iconography by considering new interpretations.

As the majority of arcs on Avery Engraved vessels have ticked or rayed secondary motifs, I believe these modifying features may further clarify the objects or the themes that the arcs symbolize. These rays and ticks may symbolize rays of sunlight, moonlight, or the flames of fire, as previously discussed. Additionally, building on recent iconographic research, scholars have compared the ticked marks that appear on the scrolls and spirals of other vessel types with imagery from engraved shell cups and gorgets. Some researchers have argued that this type of secondary, modifying motif symbolizes feathering and references the Upper World by acting as a locative - a visual element that signifies a location (Hall 1977; Reilly 2007: 47-48; Texas Archaeological Research Laboratory 2012).

Engraved shell cups and gorgets from the Spiro site feature the engraved image of "Birdman," (Figure 6) who appears to have several types of feathers. These include long flight feathers that are portrayed with ticked lines and are covering downy feathers. Downy feathers, originally thought of by scholars as flower petals and termed the "Petaloid Motif," also appear on the tail of the "Birdman" figure but with a triangular spine or quill design that denotes them as tail feathers (Reilly 2007:45). It has been argued that this petaloid motif communicates to the viewer that the image theme is celestial (Reilly 2007). As this motif occurs frequently with a "frame or border composed of bands or stripes" (Reilly:2007:46), as seen in Figure 7, I believe that it is conceivable that the ticked or rayed arcs on Avery Engraved vessels also relate to Upper World themes in this same manner by portraying the feathers of birds. The ticked arcs seen on Avery Engraved vessels may be indicative of flight feathers, while the rayed arcs may correspond to the downy feathers or flight feather spine or quill design.

Similarly, if the rayed and ticked marks on Avery Engraved vessels indeed correlate to the petaloid motif, then I propose that it is possible that the triangles on Avery Engraved vessels, when they occur as a primary motif and are not hatched or crosshatched, may

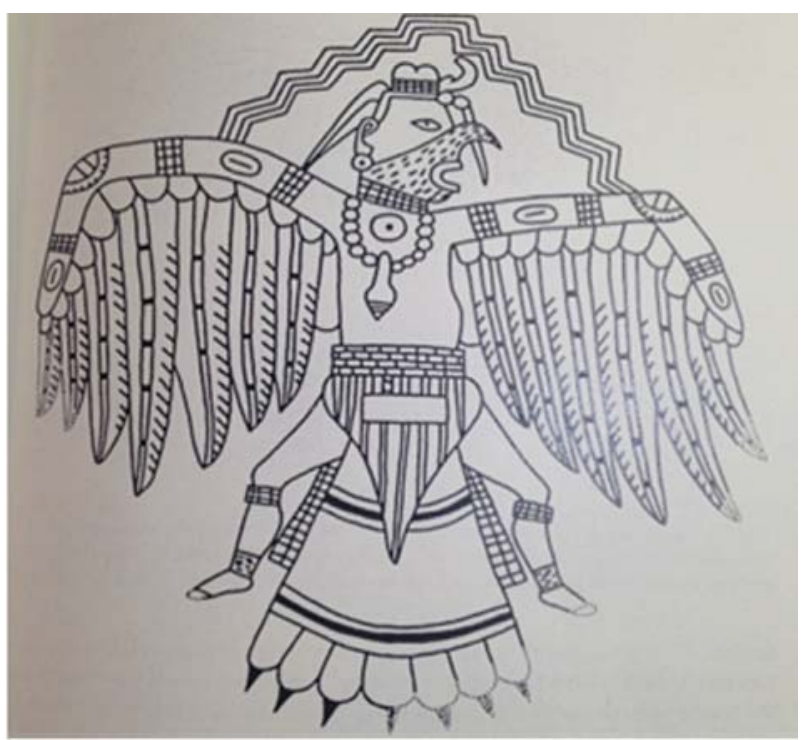

Figure 6. Birdman (from Reilly 2007; Phillips and Brown 1984:Plate 203).

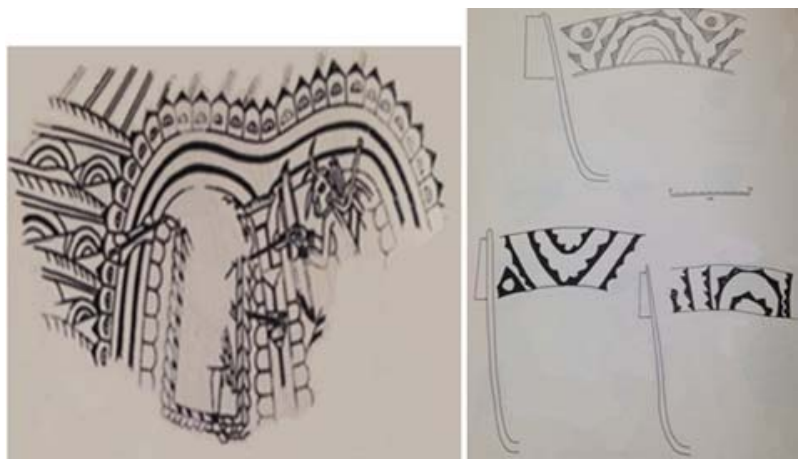

Figure 7. Right: fragmented scene on engraved shell cup of possibly a celestial sacrifice featuring the petaloid motif with triangular quills on an arc (from Reilly 2007:46; Phillips and Brown 1984:Plate 165). Left: Avery Engraved vessel imagery from the Sam Kaufman Site with rayed arcs appearing similar to the quilled petaloid motif (from Skinner et al. 1969).

be an enlarged, stylized representation of the prominent triangular-shaped tail feather quill or spine. Figure 8 shows Avery Engraved vessels with triangular motifs and engraved shell cup images that portray birds with triangles for tail and flight feathers (Phillips and Brown 1978:Plate 121, Plate 86). The vessels shown in Figure 8 also have circle motifs inside the triangle motifs. This combination of motifs is similar to those seen under the triangular quill design in Figure 7 left and on the tail feathers of birds shown in Figure 8 bottom left. On engraved shell cups, the circles located on the triangular quill design tail feathers are believed to be a "semilunar eye-motif," that also may act as a reference 

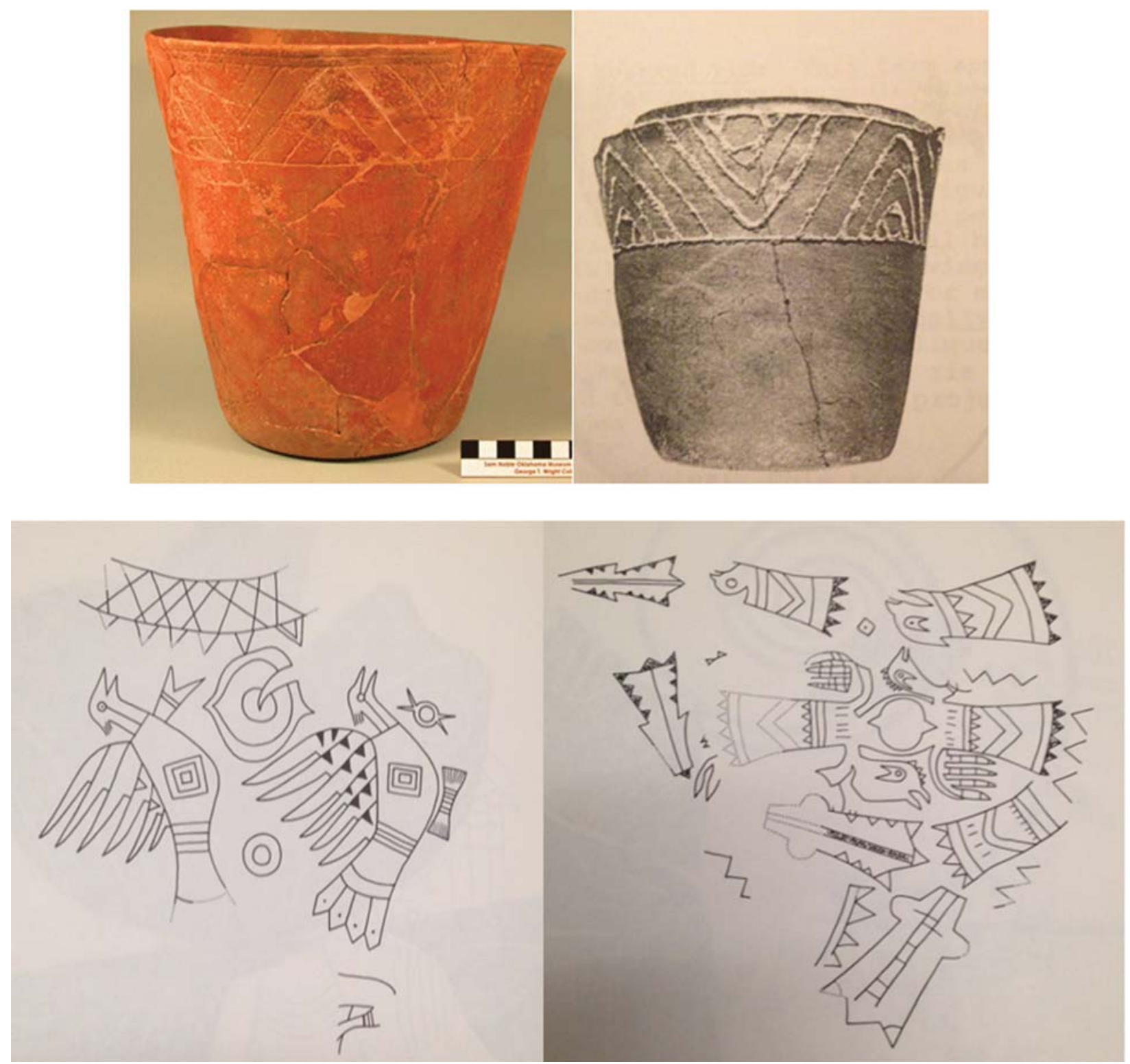

Figure 8. Top: simple bowls with concentric triangular motifs from the George T. Wright Collection and the Roden site respectively (Perino 1981:31). Bottom: Birds with triangular motifs representing feathers from engraved shell found at the Spiro site (from Phillips and Brown 1978:Plate 121, 68).

to the celestial realm (Reilly 2007:48). Reilly (2007:48) suggests that specifically this "semilunar eye-motif" may reference the celestial realm by being a "metaphor for the earth's-eye view of the starry firmament or a specific domain within the sky." When Avery Engraved vessels have triangles as a primary motif, particularly when these triangles contain circle motifs, it is possible that these also act as references to the Upper World.

Further reinforcing a feathered association with Avery Engraved vessel arc motifs, engraved shell gorgets from the Roden site in Texas and from the Spiro site in Oklahoma both depict a pair of dancers facing a pole with a shield or fan attached to their backs, as seen in Figure 9 (Gadus 2013; Phillips and Brown 1978). If these objects are indeed fans, they would have been composed of feathers; if they are portrayals of shields, then it is believed that they have a feathered petaloid motif (Gadus 2013:230). As the Spiro engraved shell gorget shows a dancer with a whole bird on his back, the association of the fan or shield with feather designs is likely an accurate one. These feathered shields or fans 

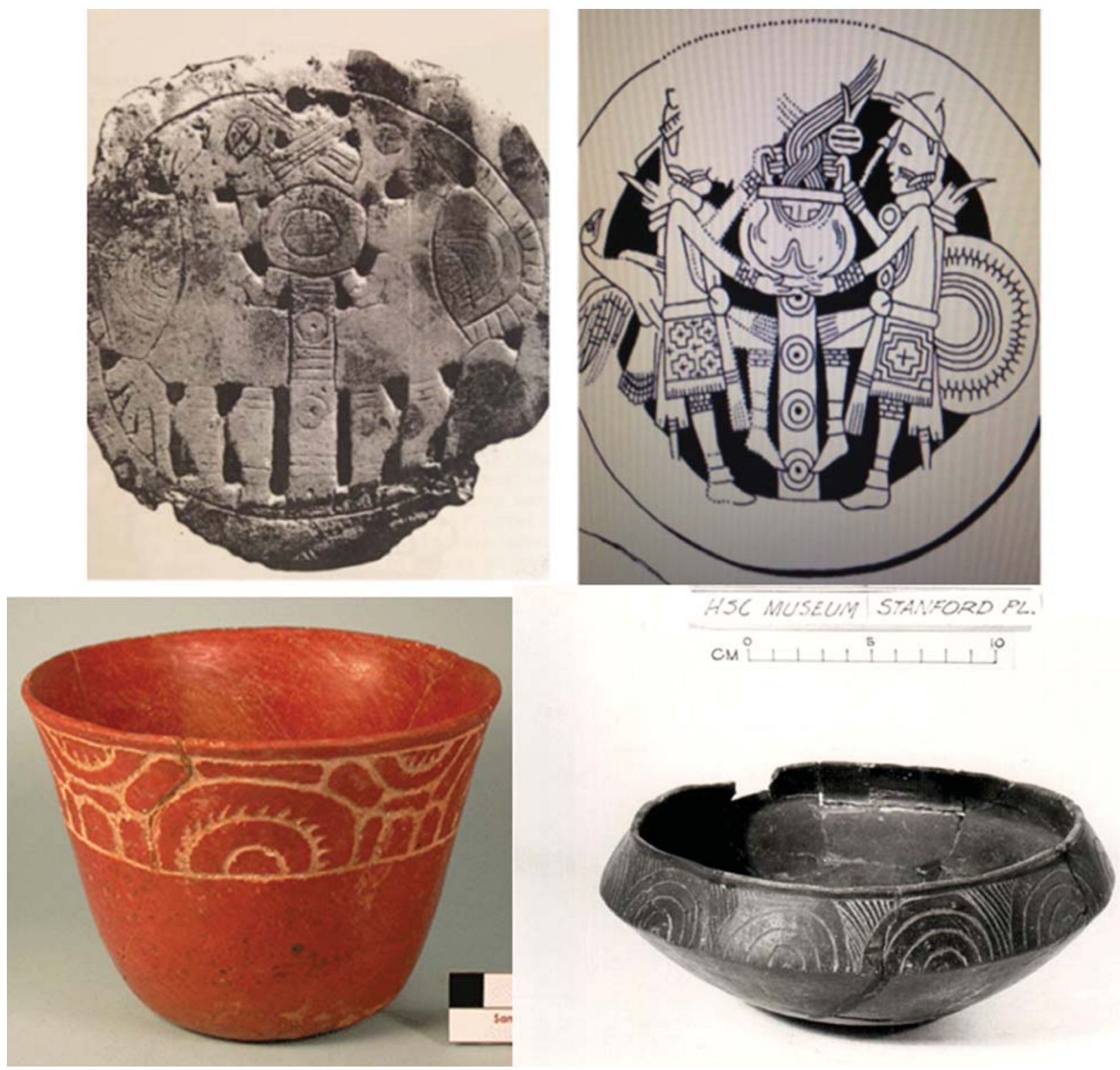

Figure 9. Top: (left- from the Roden site, right- from the Spiro site) two engraved shell gorgets showing dancers with fans or shields on their backs that appear similar to Avery Engraved plain and ticked arcs (Gadus 2013; Perino 1981:7; Phillips and Brown 1978). Bottom left: simple bowl from the George T. Wright Collection featuring the ticked arc motif. Bottom right: compound bowl from Arkansas with plain arc motif.

are depicted using arcs much like the ones found on Avery Engraved vessels, as in Figure 9.

The ticks and rays acting as flight or tail feathering along with the downy feathers may be indicative of the three cosmic realms and more explicitly could serve as references to the Upper World and to important figures such as "Birdman," who is believed to be a mythic hero who "symbolizes rebirth, the defeat of death, and continuation of social continuity" (Brown 2007; Gadus 2013:232). These themes would have been significant to Caddo society and particularly relevant to portray on objects included in burials. It therefore seems appropriate that these Avery Engraved vessels, acting as grave goods, might convey messages of renewal.

Carrying the Upper World and celestial realm interpretations of Avery Engraved vessels further in relation to their use as grave goods, the feathered petaloid motif may also signify the "Path of Souls" (Reilly 2007:47). In many Native cultures, it is believed that the dead follow the Milky Way or Path of Souls to 
reach the afterlife. For example, in a Caddo story that was titled in 1905 "Coyote Regulates Life After Death," it was recorded that "the people are taken to the sky when they die and become the stars that we see at night" (Dorsey 1905:15). Further concerning ethnographic records on the Path of Souls for the Caddo, Spanish explorer Espinosa wrote in 1746 that the souls of the deceased ascend into the air and travel to the House of Death that is situated in the south (Bolton 1987:146; Lankford 2007c). Ethnographic accounts such as these, along with archaeological material, show that traditional Caddo beliefs included the concept of the Path of Souls.

Celestial paths like the Path of Souls are portrayed on Spiro shell cups. The shell cup image with the Path of Souls in Figure 10 has an arc with the petaloid motif, which includes downy and tail feathers that have a triangular quill or spine design. The shell cup drawing featuring turkeys on a feathered celestial path in Figure 10 also prominently features ticked and rayed arcs similar to those seen on Avery Engraved vessels, such as the ones in Figure 11. It is possible that on Avery Engraved vessels, the arc motif, especially the rayed or ticked arc, refers to feathering and thus is a reference to the celestial realm and possibly to the Path of Souls.

Rayed and ticked arcs and primary triangular motifs on Avery Engraved vessels might thus be interpreted as nonrepresentational images of feathers, and therefore may act as locatives to the celestial Upper World. The possible celestial inferences of these motifs can be further modified by secondary motifs, such as hatching, which frequently occurs on bowls with ticked and rayed arc motifs, to include implications of other cosmic realms such as the Lower World. As primary triangles, ticked, and rayed arcs are argued to represent feathering with the associated act of flight suggestive of travel and movement, it is entirely possible that travel may be through the Upper World, on the Path of Souls, or through the three tiers of the universe. The lines of an arc may be acting as a path through different cosmic levels (Reilly 2007). Engraved shell cups, such as those in Figure 10, show figures both human and avian traversing on pathways that are associated with arcs (Phillips and Brown 1978:Plate 87; 1984:Plate 164). Arc motifs that do not have ticked or rayed elements symbolizing feathering may not solely reference the Upper World; similarly when ticked or rayed arcs occur with motifs that have been closely associated with the Lower World it is possible that multiple realms or the travel between realms is being referenced.

\section{Lower World Imagery on Avery Engraved Vessels}

Avery Engraved primary motifs do not all seem to carry Upper World associations. While this may seem an unusual assessment regarding vessels so commonly associated with Upper World sun motifs, I believe that certain motifs, particularly on Avery Engraved bottles, may instead reference the Lower World. The 12 analyzed Avery Engraved bottles mainly have concentric circles as a primary motif, with SZ, interlocking ends, circles, hatching, and crosshatching as secondary motifs. Including all combined Avery Engraved vessel types sampled in this study, five had the swirl or spiral motif, 11 had the interlocking end motif, 28 had the SZ motif, 22 had crosshatching, and 55 had hatching present. The watery Lower World is often represented by snakes and images pertaining to the Great Serpent, a powerful being who presided over the Lower World. The majority of the previously listed motifs have long been associated with snakes by scholars in prior iconographic studies (Dowd 2011a; Fields and Gadus 2012:514-515; Gadus 2013; Phillips and Brown 1978; Reilly 2007; Lankford et al. 2011).

Nonrepresentational references to snakes are often integrated into the $\mathrm{SZ}$ and spiral or swirl designs on engraved vessels (Dowd 2011a:Figure 8; Fields and Gadus 2013:221). Of the five Avery Engraved bowls that had swirl or spiral designs in this study, four were associated with other lower world imagery such as crosshatching, triangles, and the SZ motif. Spirals could also relate to the marine columella shell. Shell was a valued material associated with the Lower World, and shell cups were used during ceremonialism related to social integration, life, and fertility (Emerson 1989:72). The spiral motif and the interlocking ends motif also closely resemble a snake and have been compared to the canebrake rattlesnake motif that has been found on other vessels, which feature representational images of rattlesnakes (Gadus 2013:226). The SZ motif, as seen on vessels in Figure 13, is likely also closely linked to snakes due to its serpentine form and its placement on the Great Serpent's body, visible in the images 

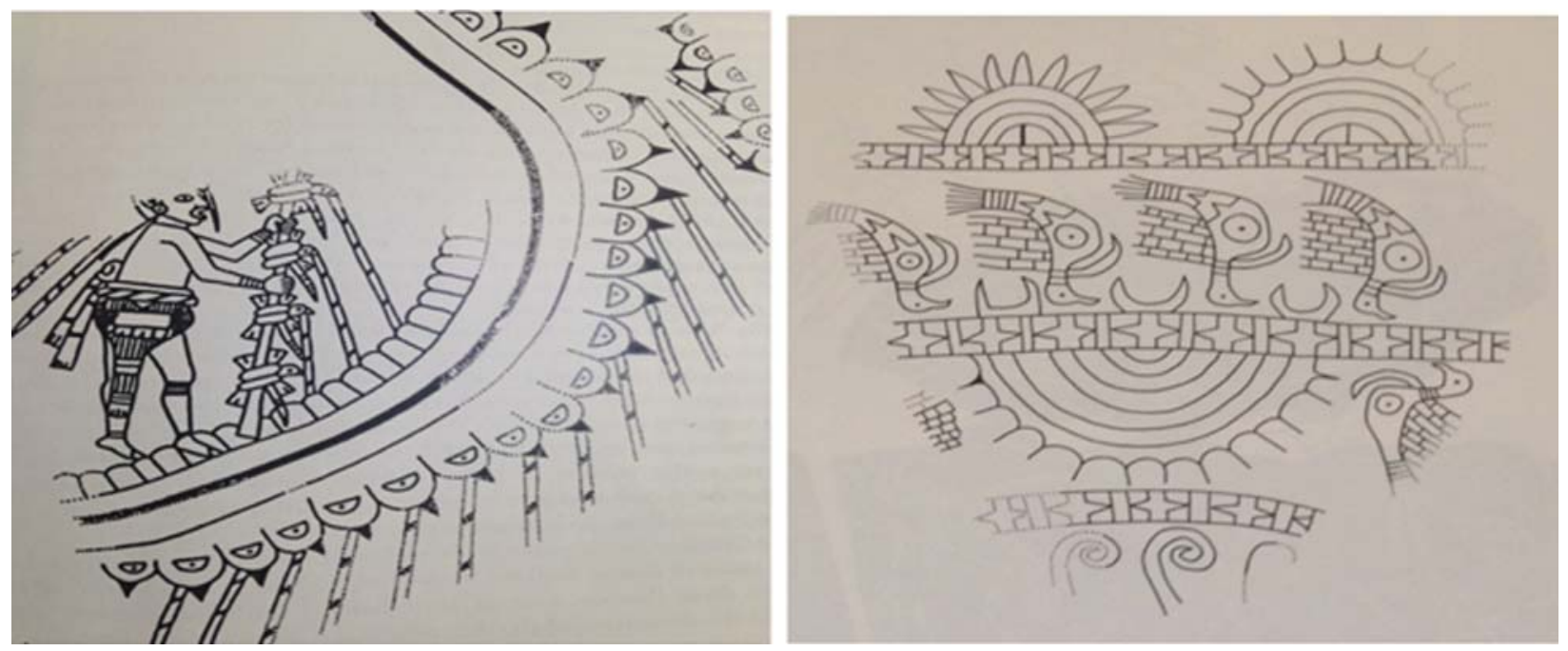

Figure 10. Left: a likely depiction of a journey on the Path of Souls, which is portrayed as an arc with the petaloid motif having a triangular quill design. Right: turkeys (Gadus 2013:233) flying on what is believed to be a feathered celestial path (Phillips and Brown 1978:Plate 87; 1984:Plate 164; Reilly 2007). Note the rayed and ticked arcs, which are similar in appearance to those found on Avery Engraved vessels (see Figure 11).

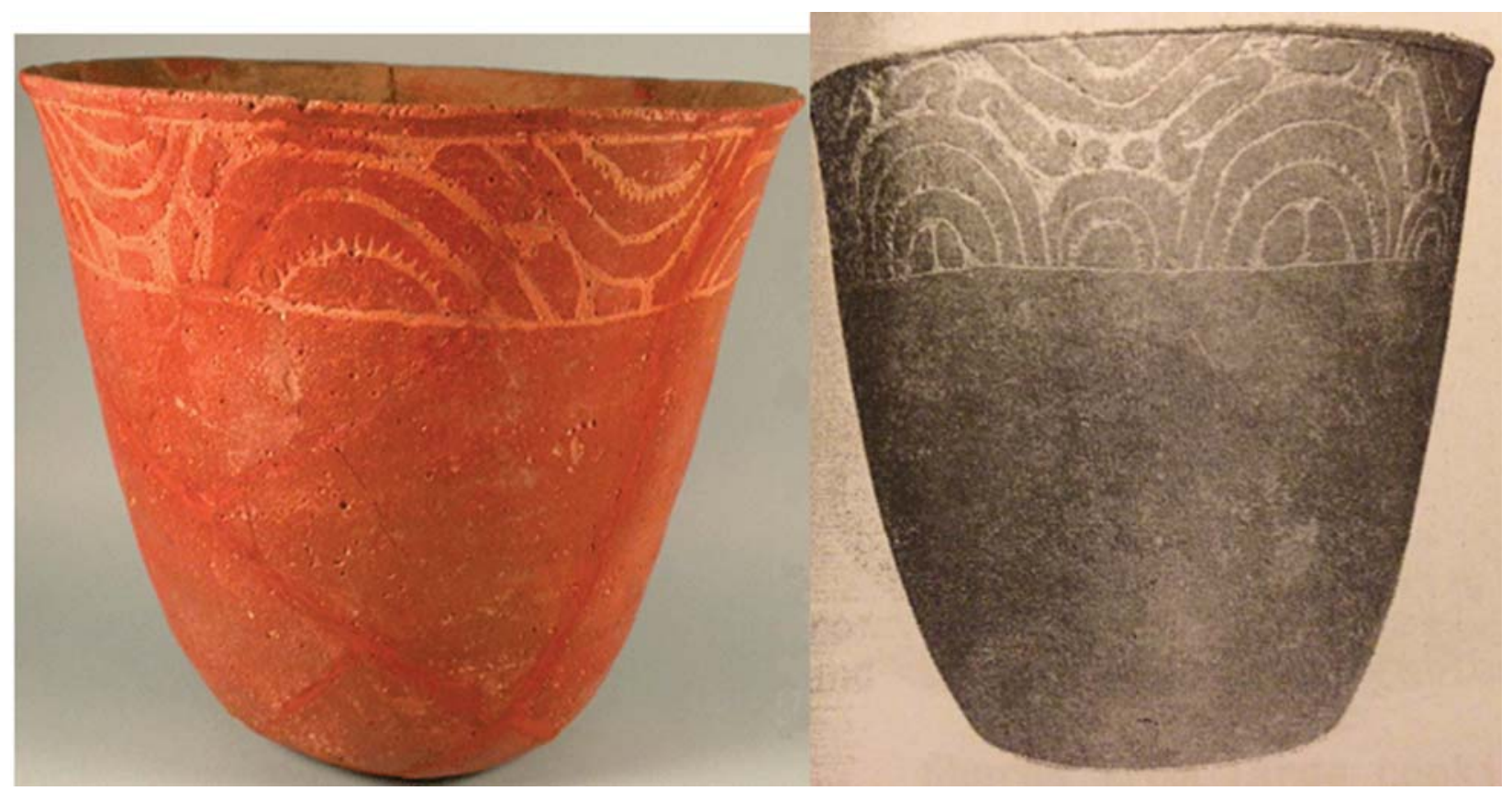

Figure 11. Left: bowl with the ticked arc motif from the George T. Wright Collection. Right: bowl from Arkansas with ticked arcs, SZ, and circle motifs.

displayed in Figure 12 (Fields and Gadus 2012:514515; Hart and Perttula 2010; Phillips and Brown 1978). There were eight Avery Engraved bowls examined that had a primary SZ motif. The most common secondary motif on these bowls was hatching. A total of 10 Avery
Engraved bottles and jars in this study had SZ motifs that were secondary to another primary motif, most commonly that of the concentric circle motif, which is also seen on Great Serpent imagery. 


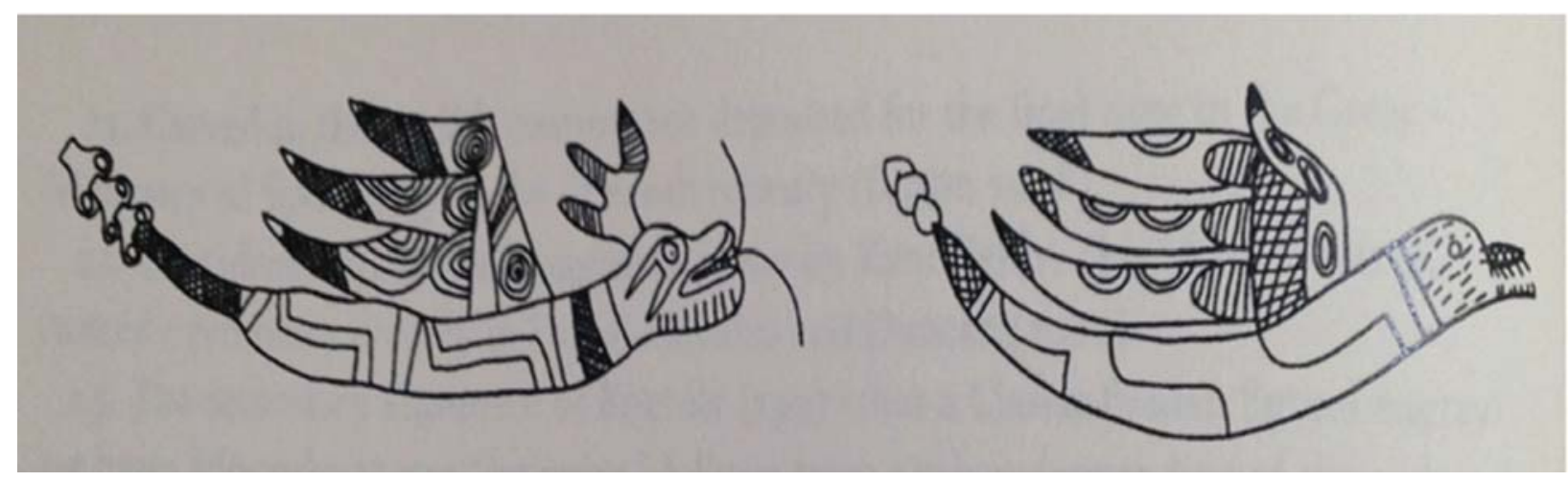

Figure 12. Images of the Great Serpent with wings on ceramics from the Mississippian site Moundville located in Alabama; images feature motifs also found on Avery Engraved vessels (see Figure 13) such as SZ, arcs, concentric circles, and crosshatching (Reilly 2007; Moore 1905:229, 1907:374).

The spiral, SZ, and interlocking ends motifs are frequently found with hatching or crosshatching. Hatching and crosshatching also occur with a wide variety of other motifs such as the rayed arc. Crosshatching is nearly always interpreted as a snake motif, as it appears on the bodies of snakes and the tails of rattlesnakes (Dowd 2011a; Gadus 2013; Pauketat and Emerson 1991; Phillips and Brown 1978, 1984). Crosshatching "symbolized renewal based on the earthly serpent's ability to shed its skin" (Dye 2012:148). These Lower World related motifs appear on other types of Avery Engraved vessels besides bottles. They also appear simultaneously with Upper World related iconography. The relationships among motifs and the combination of both Upper and Lower World iconography on Avery Engraved vessels possibly portray the multiple levels of the cosmos and the dualism that is so prevalent in the Caddo's traditional belief systems.

\section{Upper and Lower World Imagery Combinations}

Many of the Avery Engraved vessels in this study contain both Upper and Lower World motifs. While it is possible that motifs such as arcs, crosshatching, and SZ imagery have different meanings when associated together, the possibility that these motifs are dualistic or opposing in nature should not be ignored. Rather, when Upper and Lower World motifs occur on the same vessel together, the relationship and interplay of motifs and themes should be explored.

Phillips and Brown (1978:Plate 38) relate that triangles, especially hatched or crosshatched triangles, can be associated with serpents. Engraved shell cups from Spiro demonstrate how rounded triangles appear on snakes and how the heads of some snakes are triangular in shape (Phillips and Brown 1978:Plate 38). The triangular spine or quill design of tail feathers as previously discussed relating to the celestial realm has also been noted on engraved shell cups, such as on Cup 238, "snake birds" and on Cup 298, "birdman with serpentine arms" that carry Lower World connotations (Phillips and Brown 1978, 1984). Triangles on Avery Engraved vessels, when they are secondary motifs and occur with hatching or crosshatching, may possibly convey Lower World meanings. Reversely, when triangles are primary motifs and are not associated with hatching or crosshatching, they might be representative of tail feathers and signify a celestial realm as discussed previously. The triangle motif on Avery Engraved vessels, depending upon its placement and combination with other motifs, may carry entirely different meanings and cosmic associations. Arcs, particularly rayed and ticked arcs, which have also been previously discussed as possibly symbolizing feathered wings and acting as a locative for the Upper World, also occur frequently with hatching or crosshatching, which are believed to be representative of snakes and pertain to the Lower World. This combination may then reference both realms. Arcs also appear on Mississippian clay vessels that depict the Great Serpent when winged.

These representational images of the Great Serpent, including the ones shown in Figure 12, contain either the SZ motif or a triangle on the Great Serpent's body. Concentric circles and crosshatching can also be observed from these images. The Caddo possibly used these types of geometric motifs to convey a 


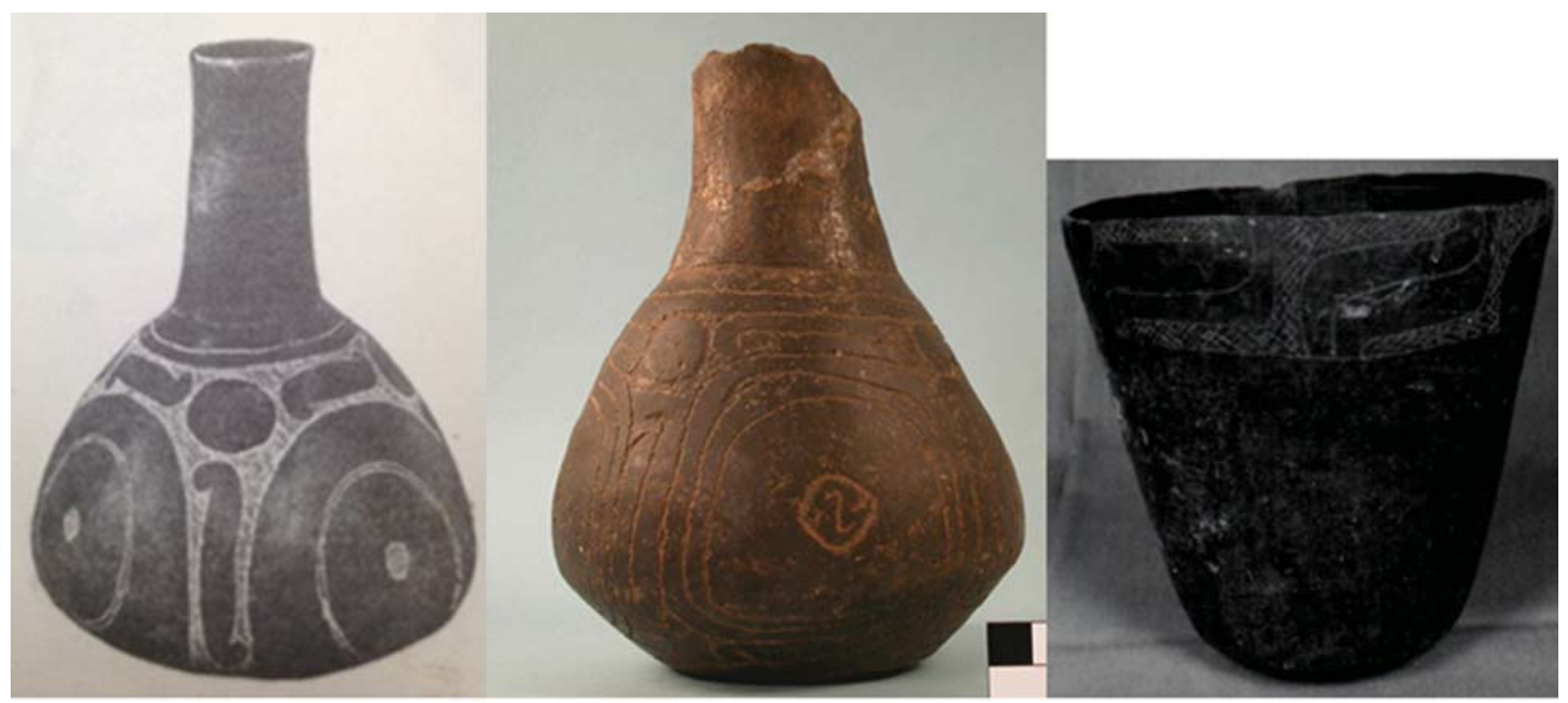

Figure 13. Avery Engraved vessels featuring motifs found on Great Serpent images. Left: bottle from the Sam Kaufman site with concentric circles, crosshatching, SZ, and circle motifs (Skinner et al. 1969). Center: bottle from the George T. Wright Collection with concentric circles, SZ, and circle motifs. Right: simple bowl from Arkansas with SZ motif and crosshatching.

nonrepresentational version of this powerful being. As scholars have noted using ethnographic information, the Great Serpent has a variety of powers, which include the ability to take on aspects of several different creatures and to transcend realms (Gadus 2013). It is argued that these different aspects "symbolize his embodiment of the above, middle, and beneath worlds" (Dye 2012:147). Avery Engraved vessels may reference multiple cosmic realms and this traversal of realms through motifs relating to the Great Serpent, feathers, and the Path of Souls.

When the Great Serpent is shown with wings, these wings likely act as a locative for the celestial realm. The Pawnee, a Caddoan-speaking group, explicitly identified the Great Serpent with the constellation Scorpio (Fletcher 1903:15). This constellation, with its serpentine form, was believed to depict the Great Serpent in the prehistoric Southeast, since the night sky was conceived as "the visible manifestation of the Lower World" (Dorsey 1905:15; Gadus 2013:239; Lankford 2007b:132-134; Reilly 2004:127). Ethnographic and ethnohistoric data reveal that the Caddo believed that, in order for the souls of deceased people to reach the Realm of the Dead, a journey on the Path of Souls or Milky Way must be undertaken; during this journey the souls may encounter obstacles such as the Great Serpent, who is the guardian of the Realm of the Dead and can either help or harm people. The deceased must correctly engage with the Great Serpent to be permitted to pass into the Realm of the Dead (Lankford 2007c:178). The interpretation that Avery Engraved vessels portray aspects of both the Upper and Lower Worlds and specific themes that may reference the Path of Souls aligns with the context of these vessels as grave goods.

The combination of Upper and Lower World motifs can both signal "action or actors in multiple world levels," as in the case with the Great Serpent, and highlight the dual, opposing forces of the cosmos (Gadus 2013:239). Knight (1981:55) has argued that a vessel itself can be considered "culturally modified earth" because it is made from clay and that the very nature of the vessel is a reference to the Middle World (Pauketat and Emerson 1991). Since the principle goal of humans residing in the Middle World was to maintain balance and harmony between the realms (Lankford 2008), using pottery to portray these Upper and Lower World themes would have been one way that the Caddo could have engaged with and communicated these fundamental religious beliefs to others in their community. 


\section{Conclusions}

\section{Directions of Future Research}

Future research projects on Avery Engraved vessel motifs could follow a number of avenues. Research could focus on possible temporal changes in motifs. It would be especially interesting to note if Lower World imagery varies over time. For this type of project, archaeological site reports would be utilized instead of museum collections so that vessels could be accurately dated. Additional, temporally related questions could center on motif differences between Avery Engraved vessels and earlier vessel type motifs such as those of Ripley Engraved vessels, which feature scroll motifs instead of arcs. The relationship between Avery Engraved vessel motifs and the earlier Sander's Plain vessels that do not feature motifs could also be explored. As Avery Engraved vessels were replaced by Taylor and Hodges Engraved vessels at the end of the McCurtain Phase and the beginning of the historic period, further research could investigate the relationship between the motifs of these two vessel types and those of Avery Engraved (Perino 1983:74).

Regional and inter-site differences in motif depictions on Avery Engraved vessels could also be a future line of inquiry. In addition, future studies could examine the motifs present on Avery Engraved vessels and large sherds from non-burial contexts, like those from storage and refuse pits and from inside house structures. Residue analysis could be performed on vessels from both burial and domestic contexts to further investigate any connections between motifs and food or beverages. This type of study could be especially relevant for Avery Engraved bottles, as bottles primarily displayed motifs that referenced the Lower World. It is possible that these bottles may have been used in a manner similar to that of engraved shell cups and contained specially prepared beverages that were to be ceremonially consumed, such as the historically known black drink that was brewed from a type of holly tree (Dye 2012:141). The possible relationship between Avery Engraved bottles and engraved shell cups could be determined and explored. Some engraved shell cups have been noted to have both rayed concentric circles and SZ elements (Phillips and Brown 1978, 1984). This combination is also seen frequently on Avery Engraved bottles.

Prospective studies could also be conducted concerning the connection between Avery Engraved vessels found within a burial context and other grave goods, particularly other vessel types. For example, at the Bob Williams Site, Avery Engraved vessels were frequently uncovered with Nash Neck Banded and Emory Punctated vessel types in graves. It would be enlightening if this co-occurrence has been found at other sites as well and if any relationships between these vessel types could be discerned.

Finally, future analysis could also center on potential correlations between Avery Engraved vessels and the age, sex, and social status of the individual with whom the vessels were interred. Fields and Gadus (2012:371-385) found at Pine Tree Mound burials of both men and women that contained vessels with imagery; however, only some adult males were interred with bottles that were adorned with imagery related to the Great Serpent. This restricted access to imagery could reflect status differences in that community. Determining if certain Avery Engraved motifs were also restricted to a particular subset of a site population, such as adult males, would contribute to studies on the social organization and stratification of Caddo sites.

\section{Concluding Remarks}

The prehistoric Caddo primarily applied nonrepresentational motifs to their pottery vessels to depict fundamental cultural, religious, and cosmological themes. To interpret and better understand these themes as they appear on pottery vessels, a comparative iconographic visual analysis between Avery Engraved vessel motifs and representational engraved shell imagery was implemented in addition to the use of ethnographic and ethnohistoric accounts and recent iconographic studies. Upon referencing the wider corpus of Mississippian and Caddo iconography, it is possible to assess Avery Engraved motifs more specifically and in greater detail rather than solely relying on the traditional conclusion of sun imagery. While it is still very possible that the rayed, ticked, and plain arcs relate to fire and the sun, it enriches and broadens our understanding of the prehistoric Caddo use of nonrepresentational 
imagery when alternative interpretations are considered. This study also expands our knowledge concerning the degree to which cosmic dualism is graphically expressed by the Caddo.

The primary arc motif, whether plain, ticked, or rayed, may reference the Upper World by symbolizing wings and feathers instead of the sun. Additionally, the unhatched primary triangular motif may also represent tail or flight feathers and refer to the Upper World.

Avery Engraved vessels often feature motifs such as SZ, crosshatching, spiral, and interlocking ends that I believe act as referents to the Lower World. Specific beings and aspects of the tiered cosmos, such as the journey to the afterlife on the Path of Souls and the Great Serpent, may also be referred to by Avery Engraved motifs. These new interpretations of motif meaning and the frequent inclusion of both Upper and Lower World motifs on Avery Engraved vessels provide a greater understanding of how the Caddo utilized abstract motifs as referents and locatives to reflect their belief in a dualistic and opposing nature of the cosmos.

\section{References Cited}

Blitz, John H.

2010 New Perspectives in Mississippian Archaeology. Journal of Archaeological Research 18(1):1-39.

Bolton, H.

1987 The Hasinais. University of Oklahoma Press, Norman.

Braun, David P.

1983 Pots as tools. In Archaeological Hammers and Theories, edited by Arthur S. Keene and James. A. Moore, pp. 107-134. Academic Press, New York.

1991 Why decorate a pot? Midwestern household pottery, 200 B.C.-A.D. 600. Journal of Anthropological Archaeology 10:360-397.
Brown, James A.

2007 On the Identity of the Birdman within Mississippian Period Art and Iconography. In Ancient Objects and Sacred Realms: Interpretations of Mississippian Iconography, edited by F. Kent Reilly and James F. Garber, pp. 56-107. University of Texas Press, Austin.

DeMarrais Elizabeth., Castillo Luis. Jamie, and Earle Timothy

1996 Ideology, Materialization, and Power Strategies. Current Anthropology 37:15-86.

Dorsey, George A.

1905 Traditions of the Caddo. Carnegie Institution of Washington Publication, Washington, D.C.

Dowd, Elsbeth Linn

2011a Amphibian and Reptilian Imagery in Caddo Art. Southeastern Archaeology 30(1):79-95.

2011b Identifying Variation: A Stylistic Analysis of Four Caddo Pottery Assemblages from Southeastern Oklahoma. Oklahoma Anthropological Society Memoir 15.

2012 Alternate Conceptions of Complexity: Sociopolitical Dynamics of the Mountain Fork Caddo. Ph.D. dissertation, Department of Anthropology, University of Oklahoma.

Dye, David H.

2012 Mississippian Religious Traditions. In The Cambridge History of Religions in America: Volume 1 Pre-Columbian Times to 1790 , edited by Stephen J. Stein, pp. 137-155. Cambridge University Press.

Emerson, Thomas E.

1989 Water, Serpents, and the Underworld: An Exploration into Cahokian Symbolism. In The Southeastern Ceremonial Complex: Artifacts and Analysis The Cottonlandia Conference, edited by Patricia Galloway, pp. 11-26. University of Nebraska Press: Lincoln and London. 
Fields, Ross C., and Eloise F. Gadus (editors)

2012 Archeology of the Nadaco Caddo: The View from the Pine Tree Mound Site (41HS15), Harrison County, Texas. 2 Vols. Reports of Investigations No. 164. Prewitt and Associates, Inc., Austin.

Fletcher, Alice C.

1903 Pawnee Star Lore. Journal of American Folklore 16:10-15.

Fogelin, Lars

2007 The Archaeology of Religious Ritual. Annual Review of Anthropology 36:55-71.

Gadus, Eloise F.

2013 Twisted Serpents and Fierce Birds: Structural Variation in Caddo Engraved Ceramic Bottle Motifs. Bulletin of the Texas Archeological Society 84:215-247.

\section{Geertz Clifford}

1973 The Interpretation of Cultures. New York: Basic Books.

Girard, Jeffrey S.

2012 Settlement Patterns and Variation in Caddo Pottery Decoration: A Case Study of the Willow Chute Bayou Locality. In The Archaeology of the Caddo, edited by Timothy K. Perttula and Chester P. Walker, pp. 239-288. Board of Regents of the University of Nebraska.

Hall, Robert L.

1973 The Cahokia Presence outside of the American Bottom. Paper presented at the Central States Anthropological Society Meetings, St. Louis, MO.

1977 An Anthropocentric Perspective for Eastern United States Prehistory. American Antiquity 42:499-518.

1997 An Archaeology of the Soul: North American Indian Belief and Ritual. University of Illinois Press, Urbana.
Hart, John P., and Timothy K. Perttula

2010 The Washington Square Mound Site and a Southeastern Ceremonial Complex Style Zone among the Caddo of Northeastern Texas. Midcontinental Journal of Archaeology 35(2):199228.

Hudson, Charles

1975 Vomiting for Purity: Ritual Emesis in the Aboriginal Southeastern United States. In Symbols and Society, edited by Carole E. Hill, pp. 93-102. Southern Anthropological Society Proceedings, No. 9.

1976 The Southeastern Indians. University of Tennessee Press, Knoxville.

Knight, Vernon James Jr.

1981 Mississippian Ritual. Ph.D. dissertation, Department of Anthropology, University of Florida.

Knight, Vernon James Jr., James A. Brown, and George E. Lankford

2001 On the Subject Matter of Southeastern Ceremonial Complex Art. Southeastern Archaeology 20(2):129-141.

Krieger, Alex D.

1946 Culture Complexes and Chronology in Northern Texas. University of Texas, Austin.

Lankford, George E.

2007a Some Cosmological Motifs in the Southeastern Ceremonial Complex. In Ancient Objects and Sacred Realms: Interpretations of Mississippian Iconography, edited by F. Kent Reilly and James F. Garber, pp. 8-39. University of Texas Press, Austin.

2007b The Great Serpent in Eastern North America. In Ancient Objects and Sacred Realms: Interpretations of Mississippian Iconography, edited by F. Kent Reilly and James F. Garber, pp. 107-136. University of Texas Press, Austin. 
2007c The "Path of Souls": Some Death Imagery in the Southeastern Ceremonial Complex. In Ancient Objects and Sacred Realms: Interpretations of Mississippian Iconography, edited by F. Kent Reilly and James F. Garber, pp. 174-213. University of Texas Press, Austin.

2008 Looking for Lost Lore: Studies in Folklore, Ethnology, and Iconography. University of Alabama Press, Tuscaloosa.

Lankford, George E., F. Kent Reilly, and James F. Garber (editors)

2011 Visualizing the Sacred: Cosmic Visions, Regionalism, and the Art of the Mississippian World. University of Texas Press, Austin.

Miller, Jay

1996 Changing Moons: A History of Caddo Religion. Plains Anthropologist 41(157):243-259.

Moore, Clarence. B.

1905 Certain Aboriginal Remains of the Black Warrior River. Journal of the Academy of Natural Sciences of Philadelphia 13:125-244.

1907 Moundville Revisited. Journal of the Academy of Natural Sciences of Philadelphia 1:335-405.

Muller, Jon

1989 The Southern Cult. In The Southeastern Ceremonial Complex: Artifacts and Analysis The Cottonlandia Conference, edited by Patricia Galloway, pp. 11-26. University of Nebraska Press: Lincoln and London.

Oxford Living Dictionaries

2016 Nonrepresentational. https://en.oxforddictionaries. com/definition/us/nonrepresentational. Oxford University Press. Accessed December 2016.

Pauketat, Timothy R., and Thomas E. Emerson

1991 The Ideology of Authority and the Power of the Pot. American Anthropologist 93(4):919-941.
Perino, Gregory

1981 Archaeological Investigations at the Roden Site (MC-215) McCurtain County, Oklahoma. Potsherd Press Publication No. 1, Museum of the Red River, Idabel, Oklahoma.

1983 Archaeological Research at the Bob Williams Site (41RR16), Red River County, Texas. Potsherd Press, Museum of the Red River, Idabel, Oklahoma.

Perttula, Timothy K.

1992 The Caddo Nation: Archaeological and Ethnohistoric Perspectives. University of Texas Press, Austin.

1996 Caddoan Area Archaeology Since 1990. Journal of Archaeological Research 4(4):295-348.

2012 The Archaeology of the Caddo in Southwest Arkansas, Northwest Louisiana, Eastern Oklahoma, and East Texas: An Introduction to the Volume. In The Archaeology of the Caddo, edited by Timothy K. Perttula and Chester P. Walker, pp. 1-26. University of Nebraska Press.

Phillips, Phillip and James A. Brown

1978 Pre-Columbian Shell Engravings from the Craig Mound at Spiro, Oklahoma Part 1. Peabody Museum Press, Peabody Museum of Archaeology and Ethnology, Harvard University, Cambridge.

1984 Pre-Columbian Shell Engravings from the Craig Mound at Spiro, Oklahoma Part 2. Peabody Museum Press, Peabody Museum of Archaeology and Ethnology, Harvard University, Cambridge.

Reilly, F. Kent, III

2004 People of Earth, People of Sky: Visualizing the Sacred in Native American Art of the Mississippian Period. In Hero, Hawk and Open Hand: American Indian Art of the Ancient Midwest and South, edited by Richard F. Townsend, pp. 125-138. Yale University Press. 
2007 The Petaloid Motif: A Celestial Symbolic Locative in the Shell Art of Spiro. In Ancient Objects and Sacred Realms: Interpretations of Mississippian Iconography, edited by F. Kent Reilly and James F. Garber, pp. 39-56. University of Texas Press, Austin.

Reilly, F. Kent, III and James F. Garber 2007 Introduction. In Ancient Objects and Sacred Realms: Interpretations of Mississippian Iconography, edited by Kent F. Reilly and James F. Garber, pp. 1-8. University of Texas Press, Austin.

Reilly, F. Kent III and James F. Garber (editors)

2007 Ancient Objects and Sacred Realms:

Interpretations of Mississippian Iconography.

University of Texas Press, Austin.

Rice, Prudence M.

1996 Recent Ceramic Analysis: Function, Style, and Origins. Journal of Archaeological Research 4(2):133-163.

Robb, John E.

1998 The Archaeology of Symbols. Annual Review Anthropology 27:329-346.

Robb, John E., (editor)

1999 Material Symbols: Culture and Economy in Prehistory. Carbondale, IL: Center of Archaeology Investigation.

Sabo, George, III

2012 The Terán Map and Caddo Cosmology. In The Archaeology of the Caddo, edited by Timothy K. Perttula and Chester P. Walker, pp. 431-449. University of Nebraska Press.

Sam Noble Oklahoma Museum of Natural History

2016 The Art of Prehistoric Caddo Potters. http:// samnoblemuseum.ou.edu/collections- andresearch/archaeology/the-art-of-prehistoric-caddopotters. Accessed October 2016.
Schambach, Frank F.

1982a The Archaeology of the Great Bend Region in Arkansas. In Contributions to the Archaeology of the Great Bend Region, edited by Frank F. Schambach and Frank Rackerby, pp. 1-11. Research Series No. 22. Arkansas Archeological Survey, Fayetteville.

1982b A Research Design for Continued Investigations of the Caddo $\mathrm{V}$ Component at the Cedar Grove Site. In Contributions to the Archaeology of the Great Bend Region, edited by Frank F. Schambach and Frank Rackerby, pp. 118-122. Research Series No. 22. Arkansas Archaeological Survey, Fayetteville.

Skinner, S. Alan, R. King Harris, and Keith M. Anderson 1969 Archaeological Investigations at the Sam Kaufman Site, Red River County, Texas. Southern Methodist University, Contributions in Anthropology No. 5, Dallas.

Simek, Jan F., Alan Cressler, and Joseph Douglas 2012 A New Overview of Prehistoric Cave Art in the Southeast. In Sacred Darkness: A Global Perspective on the Ritual Use of Caves, edited by Holley Moyes, pp.195-210. University Press of Colorado, Boulder, Colorado.

Suhm, Dee Ann and Edward B. Jelks (editors) 1962 Handbook of Texas Archaeology: Type Descriptions. Special Publication, Texas Archaeological Society and Bulletin 4, Texas Memorial Museum, Austin.

Swanton, John R.

1928 Sun Worship in the Southeast. American Anthropologist 30(2):206-213.

1929 Myths and Tales of the Southeastern Indians. Bulletin 88. Bureau of American Ethnology, Smithsonian Institution, Government Printing Office, Washington D.C. 
1942 Source Material on the History and Ethnology of the Caddo Indians. Bulletin 132. Bureau of American Ethnology, Smithsonian Institution, Government Printing Office, Washington D.C.

1946 The Indians of the Southeastern United States. Bulletin 137. Bureau of American Ethnology, Government Printing Office, Washington, D.C.

Texas Archaeological Research Laboratory

2010 The Caddo Homeland. http://www. texasbeyondhistory.net/tejas/map/index.html. Accessed November 2016.

2012 Ceramic Vessels of the Nadaco Caddo and their Links to Mississippian Iconography. http://www. texasbeyondhistory.net/pine/ceramics.html. Accessed November 2016.

Townsend, Richard F. (editor)

2004 Hero, Hawk and Open Hand: American Indian Art of the Ancient Midwest and South. Yale University Press.
Townsend, Richard F., and Chester P. Walker

2004 The Ancient Art of Caddo Ceramics. In Hero, Hawk and Open Hand: American Indian Art of the Ancient Midwest and South, edited by Richard F. Townsend, pp. 231-246. Yale University Press.

University of Oklahoma, Oklahoma Archeological Survey

Caddo Cultural Chronology. http://www.ou.edu/cas/ archsur/Caddo/cultchron.pdf. University of Oklahoma, Accessed October 2017.

Waring, A. J. Jr., and Preston Holder

1945 A Prehistoric Ceremonial Complex in the Southeastern United States. American Anthropologist 47(1):1-34.

Writing Studio Duke University

2016 Visual Analysis. https://twp.duke.edu/uploads/ assets/visual_analysis.pdf. Accessed December 2016. 